\title{
Uses and Gratifications of Internet Use among the Elderly in Turkey
}

\author{
By Nazll Aytuna* \\ Yeşim Ceren Çapraz ${ }^{+}$
}

\begin{abstract}
The present study aims to examine Internet use within Turkey's elderly population. Further, the study's objective is to record the main uses and gratifications of the elderly regarding the Internet, based on recollections of their specific experiences. The research methodology is based on semistructured interviews with 29 people older than 65 years living in Istanbul. The Internet users were selected from participants of computer training courses in Public Education Centers. The result of this study shows that the main Internet uses motivations are "searching things" and maintaining "social connectivity". However, older adults face several unique difficulties and limitations when it comes to using the Internet. A lack of self-confidence is the main concern. Privacy concerns and lack of interest are additional primary barriers to elderly users. Even if elderly persons are well educated, healthy and socially active, they use the Internet in limited ways.
\end{abstract}

Keywords: elderly, internet, Turkey, uses and gratifications theory

\section{Introduction}

The world's population is aging: every country in the world is experiencing growth in the number and proportion of older persons in their population. This growth is projected to accelerate in the coming decade (United Nations, 2015). In the case of Turkey, the elderly population 65 years and older is also the most rapidly expanding group. According to the Turkish Statistical Institution (TUIK, 2017), the elderly population was 5.682 .003 persons in 2012 , but it increased by $17.1 \%$ in the last five years, reaching 6.651 .503 persons in 2016. In 2016, $61.5 \%$ of the elderly population was in the age group of $65-74,30.2 \%$ was in the age group of $75-84$, and $8.2 \%$ was 85 and over. It is estimated that by 2023 the share of the elderly population is to be $21 \%$ of the total Turkish population (TUIK, 2017). However, this increasing elderly population has difficulties assimilating and adapting to technological development. A majority of the age group 16-24, approximately $70 \%$, declare that they have used a computer or the Internet in the last three months, compared to only $5 \%$ of the population of 65 years and older (TUIK, 2017). This digital gap is more dramatically apparent in gender difference. Only $2 \%$ of the female population of 65 years and older declared using the Internet in the last three months (TUIK, 2017).

The present study aims to examine the main uses and attitudes of the Turkish elderly regarding the Internet. It is based on recollections of their specific experiences and seeks to answer specific questions, as follows. What is the meaning of the Internet for the elderly in Turkish cultural and social

\footnotetext{
*Associate Professor of Communication Studies, Galatasaray University, Turkey.

${ }^{\dagger}$ Graduate Student in Media and Communication Studies, Galatasaray University, Turkey.
} 
contexts? What is the elderly life-world experience based on the Internet? Overall, the aging population shows lower adjustment to technological development compared to the younger generation. Demographic characteristics or physical disabilities, such as low vision, cognitive disabilities, and limitations in motor skills, are mainly considered responsible (Kurniawan \& Zaphiris, 2005). Norris (2001) adds to Castells' "informational black hole" theory by arguing that the generational difference is a key feature of adaptation to the Internet, with older portions of the population taking up use at a much slower rate. The conception of the divide also considers issues of proficiency and satisfaction. Even if gaps have diminished in terms of access (Katz, Rice, \& Aspaden, 2001; Servon, 2008), significant gaps may remain in terms of patterns of use and gratifications gained (Lazarus \& Mora, 2000; Norris, 2001). These gaps remain a persistent problem in terms of age and socio-economic status, with the poor and elderly remaining the most disconnected from the virtual world. Considering the rapid growth of the elderly population and the potential of the Internet to help them overcome their social isolation, access health information and develop and maintain their independence, this gap needs to be explored.

\section{Literature Review}

This study has applied the Uses and Gratifications Theory to explore the motivations behind elderly Internet use in the Turkish context. This is one of the influential theories in media research. The theory is concerned with the way people use media. According to the uses and gratifications perspective, people use media strategically. The theory considers not only the satisfaction of needs, but also the attitudes of the audience towards the medium and its contents. People employ different media for different purposes and, more importantly, select media choices based on how well each option helps them to meet specific needs or goals. Katz, Blumber and Gurevitch (1973) offer a typology of needs of media users, including: cognitive needs for information, knowledge, and understanding of our environment; affective needs for esthetic, pleasurable, and emotional experiences; personal integrative needs for credibility, confidence, stability and personal status; social integrative needs for contact with family, friends, and the world; and finally, escapist needs for escape, diversion, and tension release. According to this perspective, people are motivated by a desire to fulfill certain needs. Thus, rather than asking how media use influences users, a uses-and-gratifications perspective asks how users' basic needs influence their media choices. The Uses and Gratifications Theory has been applied to different media of mass communication like newspapers, radio, television and the Internet (Lull, 1982; Rubin, 1984; Lin, 1993; Stafford, Starfford, \& Schkade, 2004).

There are several studies that investigate older people's use of the Internet. For example, Morris, Goodman and Brading (2007) have conducted two connected surveys of computer and Internet use among the older population in the UK. Rates of use, computer and Internet activities, and reasons for use and non-use were investigated. The results indicate a digital divide, with many 
older people missing the benefits that computers and the Internet can provide. Hilt and Lischultz (2004) have conducted in-depth interviews on a wide range of interests and usage with elderly computer users from Midwestern states in the USA. The results of this exploratory study suggest the need for radio and television stations' websites to serve as portals through which elderly users may access information.

Another study aimed at investigating predictors of using the internet to search for online health information among Chinese older adults, who were recruited from an academic institute for older people and community centers. The frequency of Internet use and physical and psychological health were also assessed (Wong, Yeung, Ho, Tse, \& Lam, 2014). Results showed that perceived ease of use and attitudes significantly predicted behavioral intention of Internet use. In Israel, a study qualitatively compared ten older participants in computer training sessions with ten non-participants to elicit views on computer and Internet use (Blit-Cohen \& Litwin, 2004). The results of this inquiry suggest that the virtual world is a potentially important arena for the production of social capital by older adults.

In Turkey, Tekedere and Arpac1 (2006) have conducted quantitative research on 106 middle-aged and elderly people living in Ankara. The results of the survey show that among those able to use the internet, $70.5 \%$ used the Internet for research and learning, and $15.9 \%$ used it for e-mailing. As for the ones not able to use the Internet, $19.4 \%$ expressed that they wanted to learn how to use it. Furthermore, $27.4 \%$ of the individuals wanted to learn how to use social media; $45.3 \%$ thought social media is a waste of time; and $37.7 \%$ believed that it is idle work. In addition, $53.8 \%$ of the individuals wanted to use the Internet for purpose of communicating with friends, $51.9 \%$ for the purpose of education, and 57.5\% used it to chat with former friends (Tekedere \& Arpac1, 2016, p. 378). Another interesting study has compared the Internet addiction of elderly people living in Kosovo and Turkey (Abac1, Kazaz \& Başa, 2013). According to the conclusion of this study, the Internet is the basic communication and sharing platform for information (Abac1 et al., 2013).

\section{Methodology}

The research methodology is based on semi-structured interviews with 29 elderly persons living in Istanbul. The research took place over the period from November 2016 until March 2017. The youngest survey participant age was 65 years old, and the oldest was 81. According to the World Health Organization (2011), the chronological age of 65 years is the start of the age range called "elderly". The Turkish Statistical Institute indicates also that the elderly population is 65 years and over. The main explanatory variable of the research is Internet usage; education and gender difference variables are not included in this study. The research sample selected 20 Internet users and 9 non-users. The elderly non-users included both persons who have never used the Internet before and those who had some experience but stopped using it. The Internet users were 
selected from participants of computer training courses in Public Education Centers. Only those three Public Education Centers that have course participants over 65 years of age were selected: the Ataşehir Public Education Center (Ataşehir Halk Eğitim Merkezi), the Kadıköy Public Educations Center and Evening Vocational High School (Kadıköy Halk Eğitim Merkezi ve Akşam Sanat Okulu), and the Kadıköy Bostancı Public Education Center School (Kadıköy Bostanc1 Halk Eğitim Merkezi).

Each interview lasted approximately half an hour. The interviewees were asked first general questions, such as how they usually spend their day and what they like to do on weekends. Other questions were as follows: How much time do they spend with their family and what do they do? Where do they meet their friends? How much time do they spend at home? Secondly, the interviewees were asked questions about their media viewing (interaction) habits, such as how often they watch TV, and what they usually watch on TV. Do they buy and read newspapers? Which newspapers do they prefer? Questions about the Internet and computer usage habits were asked in the third section. Why do interviewees want to use a computer and the Internet? Who uses a computer and the Internet in their environment? How much time do they spend with a computer or on the Internet? Do they own a computer or tablet? Do they have Internet access at home? What do they think about the Internet? What is their purpose of using the Internet? After learning to use a computer, what are they going to do on the Internet? The final questions to interviewees concerned social media usage habits, such as their thoughts on social media. Which social media platforms do they know or use? Do they have social media accounts? Do their friends use social media?

\section{Research Results}

The result of this study shows that elderly Turkish persons, who are capable of using the Internet, are using the Internet in more restricted ways and less often than other age groups. Even though they have more free time than any other age group, the gap of use is evident. For elderly users, help and encouragement of family members or training centers is mandatory. The main motivations for internet use can be considered as "searching things" and maintaining "social connectivity". Almost all interviewees were active conventional media users. The Internet has changed their newspaper reading habits. Reading newspapers online is a common activity. Additionally, playing games and listening to music are also mentioned as main Internet activities. The interviewees affirmed some positive attitudes toward the Internet, such as a feeling of being fresh and comfortable, the provision of an edge over others, and hours of leisure. 


\section{Internet and Computer Usage}

Older people use search engines to research specific subjects, to read news about current events, to research vacations and travel information, and for checking weather information. For elderly users, the Internet is an efficient means for finding information. In opposition to other research topics, a search for health information was rarely initiated.

I like to search some stuff. For example, I search for poems, but not a deep search of course. I do not have much time, because my husband is so sick. (E., Female Interviewee, Age 72, and Retired Agriculture Engineer)

When something was stuck in my head, I go and search for it than you are discovering the world. (E., Female Interviewee, Age 72, and Retired Agriculture Engineer)

I go straight to Google when I get something in my head now, before I was looking at the encyclopedia. (F., Female Interviewee, Age 81, and Retired University Employee)

Before the internet, there was only home phone. If you were not at home, you would not get news from anyone. For now, I know where she is, what she is doing, what is going on all over the world. (T., Female Interviewee, Age 70, and No Professional Experience)

I have not learned to make an appointment to see a doctor. My son takes care of my appointments, but I want to be able to make this. I should not need any more help. (T., Female Interviewee, Age 70, and No Professional Experience)

The Internet also presents opportunities for older people to socialize and establish social networks. For older people with mobility problems or geographically far away from their family members, Internet facilities such as email or instant messaging provide needed social support from distant family members.

I feel more comfortable. If I did not learn to use it, I could not get news from my child. (E., Female Interviewee, Age 65, and No Professional Experience)

I have many friends on Face (Facebook), with whom I am always in contact. When someone has died or when someone was born, we are communicating from there with each other. (Y., Female Interviewee, Age 73, and Retired History Teacher)

I feel more comfortable and fresh, I am proud of myself, for example, even the superior ones cannot do it. I am happy to say that at my age it can be learned. (M., Female Interviewee, Age 81, and Retired University Employee)

I think that the internet is nice in terms of communication. We do not feel alone or strange, we are more aware of each other thanks to the internet. (S., Female Interviewee, Age 65, and Retired English Teacher) 
My goal in learning the internet was to be able to send e-mail to my friends. For example, I am sending e-mail attached a picture on my friends' birthday, I like this so much. (M., Female Interviewee, Age 69, and Retired Teacher)

I have found all my high school friends on Facebook. I am glad to keep in touch with my old friends. We cannot see each other all the time, but I feel happy when we are communicating from there. It is great, but I feel that I cannot keep up with technology. (T., Female Interviewee, Age 65, and Retired Executive Assistant)

I started using the internet after my son moved to Germany. Normally, the phone calls between the two countries are very expensive; I cannot call my son every day. Thanks to the internet, we can keep in touch all the time, and it is cheap. So using the internet is important for me. Without it, I could not see and get news from my son. Every day they send me a photo. (N., Female Interviewee, Age 65, and No Professional Experience)

I enjoy spending my time on the internet looking at Facebook because it keeps me busy, especially in retirement. (C., Male Interviewee, Age 70, and Retired University Employee)

Older adults face several unique difficulties and limitations when it comes to using the Internet. A lack of self-confidence is the main concern. Elderly people in general do not feel that computers (and the Internet) are meant for their use. They feel that computers are for younger people. In fact, they generally accept that they will be unable to become experts in computer use. Privacy concerns and lack of interest are additional barriers to elderly users.

My friends who use Facebook and Instagram are younger than me. But they never exclude me because of my age; they are so surprised that I use it at this age. (A., Female Interviewee, Age 75, and Retired Medical Doctor)

It is complicated for me. I am asking the same questions many times. The computer is difficult. (M., Male Interviewee, Age 81, and Retired University Employee)

It is cool! I wish I was young and I grew up with Internet. (H., Male Interviewee, Age 67, and Retired Designer)

A few years ago, my son brought a computer for me. Once, I tried to open it, but it locked, I did not understand what happened. I scared. Then, my son came home and started yelling at me because of locked computer. After that, I decided to start computer course. I could not open it until I participated in a computer course. (A., Female Interviewee, Age 81, and Retired Medical Doctor)

I am mostly looking at Facebook but I am not writing something to someone because texting is getting harder at my age. (M., Male Interviewee, Age 65, and Retired Flight Planner) 


\section{Interaction Habits}

Interactivity has been defined as "the degree to which participants in the communication process have control over, and can exchange roles in their mutual discourse" (Williams, Rice and Rogers, 1988, p. 10). Kaye and Johnson (2001) state that Internet users are more actively involved and engaged in using the Internet because of its interactivity. However, older adult users have limited interest in interactive patterns of the Internet. Instead, they engage in only a small range of activities. They are more likely to focus on searching and watching. They are less interested in sharing and downloading content, as well as being interactive. As such, their social interaction, which includes both the exchanges of information among persons and groups online, is restricted. This is because elderly Internet users do not like to expose their privacy online. Even if elderly persons are well educated, healthy and socially active, they use the Internet in limited ways. Sometimes family members also cause this limitation. Regardless of the source, the interviewees often pronounce privacy concerns.

Sometimes I want to express some of my political views, but my son says do not do it. (M., Male Interviewee, Age 81, and Retired University Employee)

I am a lawyer. I was a "dinosaur" until recently, and I even did not touch the computer's keyboard. Now I am learning a little bit. However, I do not send documents over the internet. I do not send it because I cannot trust the system. If there is any interruption, it may cause a legal problem. (H., Male Interviewee, Age 69, and Lawyer)

I do not put my very special photos on the Internet. I am putting collective photos with friends. For example, I do not put myself in private. (N., Female Interviewee, Age 65, and No Professional Experience)

Unlike the young people, I avoid sharing my private life on Facebook. I share only useful information. (S., Female Interviewee, Age 65, and Retired English Teacher)

I do not usually the internet outside, out of emergency. I have checked just phone calls and text message, not internet based application such as email or others. I check my email at home because the internet, for me is home activity. (M., Female Interviewee, Age 67, and Retired University Employee)

I do not like to be seen on the internet. My daughter shared and tagged my photo to celebrate my teacher's day. I like this, but I do not usually share something. I just press the like button on Facebook. (F, Female Interviewee, Age 69, and Retired Teacher)

I can be online after $10 \mathrm{pm}$. I cannot look at the internet during the day because I have a lot of housework to do. While my husband is sleeping, I can open my computer. (T., Female Interviewee, Age 70, and No Professional Experience)

Lack of interest also exists, but this is mostly caused by misunderstandings, such as computers being unsuitable, unnecessary, or too complicated for older people. The general notion is that age is perceived as a barrier. Many elderly 
people were not interested in using computers or the Internet, because they did not know what they could do with them.

My daughter offered me to buy a computer a few years ago. I was not very interested. My husband was asking me to search for medical information. I was looking at things like that. Now I have been constantly switching on computers to practice what I have learned, so I am interested. (M., Female Interviewee, 79 Age, and Retired Accountant)

I actually have many libraries in my house, so I came here to learn to answer the incoming messages. (K., Male Interviewee, Age 80, and Retired Consulate Employee)

The question: Would you listen to music from YouTube or do you ever watch a movie or something else from the Internet? "No, I do not care about them at all. I never play games. I do not have time, because I am closer to death now, I need to evaluate the time as much as possible". (A., Female Interviewee, Age 75, and Retired Medical Doctor)

I have no internet access at my home; I do not need at all. I am using the computer/ internet at the computer course, but I feel that I have to provide the internet access at home. Whoever comes to my home asks firstly whether there is internet or not. (H., Male Interviewee, Age 67, and Retired Designer)

\section{Reasons for Non-Use}

Several studies have asked elderly users directly about their reasons for disengagement; and the reasons consistently mentioned are feeling too old, a lack of Internet experience or Internet skills, insufficient time and high connection costs (Helsper \& Reisdorf, 2013; Lee, Chen \& Hewitt, 2011; Millward, 2003; Morris et al., 2007; Peacock \& Künemund, 2007). Most often, elderly nonusers are described in terms of socio-demographics particularities, such as gender, education and household composition (Helsper \& Reisdorf, 2013, Morris et al., 2007). This research indicates that elderly people feel uncomfortable with technology in general; this is a common point between users and non-users. Specifically, elderly people believe they are not able to control or manage (new) technology. They usually depend on others to help them. They do not feel comfortable or able to interact with (new) technologies by themselves. In case something goes wrong, they do not feel to be able to fix a problem by themselves.

Some elderly people have affirmed negative attitudes toward the Internet. According to these individuals, the Internet is a source of violence that diffuses bad habits to the society. In this study, when being asked about the reasons for disengaging, interviewees did not mention cost or access difficulties at all. Usually, they cited a lack of interest and health problems. In addition, most of them were concerned about lack of skills and ability. Demographic characteristics or physical disabilities such as low vision, cognitive disabilities, and motor skill limitations are mainly responsible. The insufficiency of education is another key problem. While the proportion of illiterate elderly population in Turkey was $29.2 \%$ in 2011, it decreased to $21.9 \%$ in 2015 (TUIK, 2017). 
The Internet is not going to change everything. One finds a girl, and the other finds a husband. Yes, that has happened in my village. She found a husband from the Internet in our age, in my environment, generally they go to their village. What to do with the Internet there. (M., Female Interviewee, Age 77, and Illiterate)

Since the Internet came into our life, violence against women has increased. The state must restrict the usage. Anyway, it is too late to use the Internet. We are not able to see without wearing glasses. (T., Male Interviewee, Age 73, and Elementary School Graduate, Retired Factory Worker)

Believe me, I do not have time at all. Actually, I went to a computer course five years ago but since then I did not touch it. However, I have a nice certificate, and I show it proudly. Then I forgot it. (N., Female Interviewee, Age 67, and Retired Teacher)

What can I do on the internet at my age? I am not willing to use the internet, but I have just learned how I can listen to the Quran on YouTube from my Smartphone. I can call, that is all. (M., Female Interviewee, Age 77, and Illiterate)

I think it is nice to learn the Internet. Even to make an appointment to see a doctor is very important. You can find everything. If I believe that I could learn I can buy immediately. They show something I forget suddenly. (A., Female Interviewee, Age 79, and Elementary School Graduate)

Tablets, for instance, my grandson showed me how to download a picture. Afterwards, I could not repeat it. (A., Female Interviewee, Age 79, and Elementary School Graduate)

I would like to use, but in my age, I do not want anymore, I would love to, if I had learned in time. (E., Female Interviewee, Age 81, and No Educational Grade)

\section{Conclusion}

The purpose of this research was to explore the uses and gratifications of elderly Turkish Internet users. Data were combined from the semi-structured interviews in Istanbul. The findings confirm previous studies realized in different socio-cultural contexts that indicate the elderly population's difficulties with assimilating and adapting to the Internet. Otherwise, the present study confirms the findings of the age based digital divide. A comparison with the study that we have conducted on children's Internet use in Turkey gives a clear sign of this digital divide (Aytuna, Toksöz, \& Öztemir, 2014). The results of the present study also indicate some reasons why older people do not use the Internet at all or use it in a limited way. A lack of self-confidence and a lack of interest are the main concerns. Participants identified the internet as a young people's activity. In other words, for some participants, youthful dynamism is an obligatory condition for being active on the Internet. Apart from usage difficulties, some participants have affirmed negative feelings, such a perception of a danger to society. On the other hand, some of the participants have affirmed positive feelings, such as feeling proud of 
themselves and stimulated by using the Internet at their age. In addition, they have affirmed that using the Internet contributes to feelings of being updated and social. The findings of the study also point out some remarks on promoting effective Internet usage by the elderly, such as the importance of training courses to resolve negative attitudes toward Internet. Additionally, it shows that family members are playing an important role in motivating the elderly to start using the Internet.

The present study has limitations regarding the data collected. Research was conducted only in Istanbul, where Internet use as a percentage of the local population is at the top level in Turkey. This study represents an initial attempt to characterize different attitudes of the Turkish elderly regarding the Internet.

\section{Acknowledgement}

This paper has been financially supported by Galatasaray University Research Fund under Grant no 17.300.004.

\section{References}

Abac1, R., Kazaz, N., \& Başa, B. (2013). The Internet Addiction of Kosovo and Turkey Elderly People. Procedia-Social and Behavioral Sciences, 103, 1104-1117.

Aytuna N., Toksöz D., Öztemir N. (2014). Dijital Yaşan Çocuklar? Çocukların Bilgisayar ve İnternet Kullanımı (Children Living Digital? Children's Computer And Internet Use). TRT, 149-172.

Blit-Cohen, E., \& Litwin, H. (2004). Elder participation in cyberspace: A qualitative analysis of Israeli retirees. Journal of Aging Studies, 18(4), 385-398.

Helsper, E. J., \& Reisdorf, B. C. (2013). A quantitative examination of explanations for reasons for internet nonuse. Cyberpsychology, Behavior, and Social Networking, 16(2), 94-99.

Kaye, B. K., \& Johnson, T. J. (2001). A Web for all reasons: The uses and gratifications of Internet resources for political information. Paper presented at the Association for Education in Journalism and Mass Communication, Washington DC.

Kurniawan, S., \& Zaphiris, P. (2005, October). Research-derived web design guidelines for older people. In Proceedings of the 7th international ACM SIGACCESS conference on Computers and accessibility (pp. 129-135). ACM.

Hilt, M. L., \& Lipschultz, J. H. (2004). Elderly Americans and the Internet: E-mail, TV news, information and entertainment websites. Educational Gerontology, 30(1), 57-72.

Katz, E., Blumler, J. G., \& Gurevitch, M. (1973). Uses and gratifications research. The Public Opinion Quarterly, 37(4), 509-523.

Katz, J. E., Rice, R. E., \& Aspden, P. (2001). The Internet, 1995-2000: Access, civic involvement, and social interaction. American Behavioral Scientist, 45(3), 405-419.

Lazarus, W., \& Mora, F. (2000). Online Content for Low-Income and Underserved Americans: The Digital Divide's New Frontier. A Strategic Audit of Activities and Opportunities. Children's Partnership, Santa Monica, CA. Retrieved from goo.gl/ $5 \mathrm{~J} 3 \mathrm{G} 7 \mathrm{~m}$. 
Lee, B., Chen, Y., \& Hewitt, L. (2011). Age differences in constraints encountered by seniors in their use of computers and the internet. Computers in Human Behavior, 27(3), 1231-1237.

Lin, C. (1993). Modeling the gratification-seeking process of television viewing. Human Communication Research, 20(2), 224-244.

Lull, J. (1982). How families select television programs: A mass-observational study. Journal of Broadcasting, 26(4), 801-811.

Millward, P. (2003). The "grey digital divide": Perception, exclusion and barriers of access to the Internet for older people. First Monday, 8(7).

Morris, A., Goodman, J., \& Brading, H. (2007). Internet use and non-use: views of older users. Universal Access in the Information Society, 6(1), 43-57.

Norris, P. (2001). Digital divide: Civic engagement, information poverty, and the Internet worldwide. London: Cambridge University Press.

Peacock, S. E., \& Künemund, H. (2007). Senior citizens and Internet technology. European Journal of Ageing, 4(4), 191-200.

Rubin, A. M. (1984). An examination of television viewing motives. Journal of Communication, 8(3), 141-165.

Servon, L. J. (2008). Bridging the digital divide: Technology, community and public policy. London: John Wiley \& Sons.

Stafford, T. F., Stafford, M. R., \& Schkade, L. L. (2004). Determining uses and gratifications for the Internet. Decision Sciences, 35(2), 259-288.

Tekedere, H., \& Arpacı, F. (2016). Orta Yaş ve Yaşlı Bireylerin İnternet ve Sosyal Medyaya Yönelik Görüşleri (Opinions of Middle and Old People Towards Internet and Social Media ). Türkiye Sosyal Araştırmalar Dergisi, (2), 377-392.

TUIK - Turkish Statistical Institute. (2017). Household information technologies usage survey. Issue no: 24862 . Retrieved from goo.gl/bZ6ivo.

United Nations, Department of Economic and Social Affairs, Population Division. (2015). World Population Ageing 2015. (ST/ESA/SER.A/390). Retrieved from goo.gl/GV Kr7D.

Williams, F., Rice, R. E., \& Rogers, E. M. (1988). Research methods and the new media. New York: Free Press.

Wong, C. K., Yeung, D. Y., Ho, H. C., Tse, K. P., \& Lam, C. Y. (2014). Chinese older adults' Internet use for health information. Journal of Applied Gerontology, 33(3), 316-335.

World Health Organization. (2011). Global Health and Aging. Retrieved from goo.gl/ JRaKn. 
